\title{
OBITUARIES IN TRANSLATION: A CORPUS-BASED STUDY
}

\author{
Rozane Rodrigues Rebechi ${ }^{1}$ \\ Márcia Moura da Silva ${ }^{1}$ \\ 1 Universidade Federal do Rio Grande do Sul, \\ Porto Alegre, Rio Grande do Sul, Brasil
}

Death can make a good story. (Starck 2006, ix)

\begin{abstract}
Sooner or later death will affect everyone, everywhere. However, this harsh reality is faced differently across cultures. Obituaries can help unveil some of those differences and their impact on translation. Using corpus linguistics as methodology, we aim to investigate if - and to what extent - a comparable American English-Brazilian Portuguese corpus of obituaries can help with the task of raising students' awareness of cultural peculiarities encountered in the same genre written in different languages and their consequences for equivalence retrieval. In order to accomplish our task, we selected texts published in Brazilian and NorthAmerican newspapers in 2015 and 2017. Despite addressing an everyday subject, obituaries are little explored academically. Nevertheless, this neglect is not proportional across countries, but it results from the popularity enjoyed by the genre. While obituaries are widely read in the United States, in Brazil they are rare, almost solely dedicated to famous deceased. Qualitative and quantitative analyses showed that terminology lacks in Portuguese due to cultural differences regarding the theme and that the lack of contact with the genre, in addition to ritual differences encountered in both countries/cultures, can help explain difficulties faced by Brazilian undergraduate students of Translation to render NorthAmerican obituaries into Portuguese.
\end{abstract}

Keywords: Obituary; Corpus linguistics; Death notice; Translator training. 


\title{
OBITUÁRIOS NA TRADUÇÃO: UM ESTUDO BASEADO EM CORPUS
}

\begin{abstract}
Resumo: Mais cedo ou mais tarde, a morte afetará todas as pessoas, em todos os lugares. No entanto, essa dura realidade é enfrentada de formas diferentes em culturas distintas. Os obituários podem ajudar a revelar algumas dessas diferenças e seu impacto para a tradução (Loock \& Lefebvre-Scodeller, 2014). Usando a Linguística de Corpus como metodologia (BAKER, 1993; LAVIOSA, 2002; McENERY \& HARDIE, 2012; PHILIP, 2009; ZANETTIN, 2012), investigamos se - e até que ponto - um corpus comparável de obituários em inglês estadunidense e em português brasileiro pode ajudar na tarefa de conscientizar os aprendizes sobre as peculiaridades culturais observadas em um mesmo gênero textual escrito em diferentes idiomas, e suas consequências para a identificação de equivalentes. Para atingir nossos objetivos, selecionamos textos publicados em jornais brasileiros e estadunidenses entre 2015 e 2017. Apesar de abordarem um assunto cotidiano, os obituários são pouco explorados academicamente. No entanto, essa negligência não é proporcional nos dois países, e resulta da popularidade do gênero. Enquanto nos Estados Unidos os obituários são lidos regularmente, no Brasil eles são raros, quase exclusivamente dedicados a falecidos famosos. Análises qualitativas e quantitativas mostraram que a ausência de termos em português se deve a diferenças culturais que permeiam o tema, e que a falta de familiaridade com o gênero, além das peculiaridades dos rituais praticados nos dois países/culturas, pode ajudar a explicar as dificuldades enfrentadas pelos aprendizes brasileiros na tarefa de traduzir obituários estadunidenses para o português brasileiro.
\end{abstract}

Palavras-chave: Obituário; Nota de falecimento; Linguística de Corpus; Formação de tradutores.

\section{Introduction}

According to Bates et al. $(2009,2)$, "The way a culture chooses to commemorate its dead reflects a great deal about the character and nature of that culture". If we consider this claim to be true, it can be concluded that Brazil and the United States are at opposite sides, culturally speaking, since death, a fact common to all peoples, 
is approached so differently in these countries. And obituaries can help unveil some of these differences.

After analyzing the essence of contemporary North-American obituaries, Bates et al. (2009) concluded that obituaries draw audience to newspapers, corroborating the claim of a former The Sydney Morning Herald's editor-in-chief: “In the English-speaking world, a newspaper of quality hardly seems complete these days without a regular obituary page" (Starck 2006, x). In Brazil, on the other hand, the theme is far from popular. Here obituaries are mostly dedicated to the death of renowned people in the form of news articles written by journalists and published in newspapers and magazines. Exceptions are death notices, paid texts which are usually short and restricted to providing information about the (bygone) funeral.

Despite its far-reaching qualities in North-American culture, however, the theme is not free from prejudice, as we can illustrate with a passage from the movie Closer. When asked about his profession, Dan Woolf, the character played by Jude Law, laments: "Well, I had dreams of being a writer, but I had no voice. What am I saying? I had no talent. So I ended up in obituaries, which is the Siberia of journalism." (Nichols et al. 2004). When it comes to academic research, this theme is also underexploited. Eid (2002) noticed that when talking about her research - the analysis of gender across cultures through obituaries -, she was constantly faced with two antagonistic reactions: some people were shocked by the choice of such macabre topic of study, while others were glad to know they shared an interest in the topic. The latter reaction could perfectly suit those North-American newspaper readers who check the obituaries on a regular basis, whether for information or for enjoyment of their literary quality. Most Brazilians, on the other hand, would probably belong to the 'shocked' group, as a consequence of our limited exposure to the topic. But differences surely go beyond readers' interest in the genre.

When comparing two societies such as Brazilian and NorthAmerican, practical issues also help explain the divergence in 
approaching the subject. For instance, while North-American funerals may last several days, since they involve, among other steps, mourning the deceased, celebrating their life, and offering support to the family, Brazilians tend to proceed with burial or cremation in no more than 24 hours after death. A hypothesis is that the physical presence of the dead person causes such a grief that the ceremony is usually abbreviated. Scientific studies corroborate this discrepancy. During a six-month research at the Children's National Medical Center of the George Washington University, Regina Bousso, a Brazilian Professor of Nursing, concluded that North-American health professionals are inclined to speak more naturally about death among themselves and to the patients' relatives than their Brazilian counterparts (Fioravanti 2016). For comparison purposes, the researcher emphasizes that Brazilian schools have broken old barriers by including formerly avoided topics (e.g., sex) in their curricula, but death and mourning are still taboo in the country. In the United States, on the other hand, people tend to be more open when it comes to the end of life. There, $78 \%$ of elderly patients discuss with their family and friends the kind of treatment they expect in case they are unable to decide for themselves.

Although, as previously mentioned, obituaries are not a popular research topic, there are some noteworthy research in English on the subject. Some examples are Eid's (2002) examination of crosscultural differences in Egypt, the United States and Iran; Moses and Marelli's (2004) analysis of the construction of life and death through the language of obituaries; Moore's (2002) intention to unveil how much of The Economist's ideology can be revealed by the obituary column; Bates et al.'s (2009) attempt to examine the characteristics of contemporary North-American obituaries; and possibly the most prolific scholar in the area, Starck $(2005,2006$, 2008, 2009) has examined obituaries from different perspectives, ranging from gender to sexist issues. In Brazil, academic research on the theme is scarce. Exceptions are Vieira (2014), whose dissertation thesis analyses North-American obituaries as a specific 
genre which reflects current wishes, and Cimminiello and Tambelli (2012), who propose the use of obituaries as a genre to be discussed in the classroom.

Considering that obituaries can unveil important cultural differences, which also have impact on bilingual terminology, and as such they constitute an interesting genre to be used in translation classes, we intend to verify if - and to what extent - a comparable English-Portuguese corpus of obituaries can help overcome translation difficulties. In order to accomplish our objective, we applied corpus-based methods to translation studies (Laviosa 2002, Zanettin 2012), which we detail further below.

\section{Obituary as a theme for translation training}

Although generically referred to as 'obituaries', reports of death may vary considerably in length, content, authorship, and status of the honored. North-American larger newspapers - such as The New York Times and Chicago Tribune - usually restrict the session 'obituaries' to edited news articles dedicated to renowned deceased, typically including an account of their lives. Common people's passing, on the other hand, is listed under 'death notices', paid advertisements which may range from short texts with information about the upcoming funeral to memorial advertisements with biographical details about the deceased. The latter are usually written by the family members, with or without help from a funeral home, and are prototypical texts which may include dates of birth and death, schools attended and jobs performed, hobbies, names of predeceased and surviving relatives, donation request, and information about funeral services. It is advisable that death notices should be published one or two days prior to the beginning of services. ${ }^{1}$

1 Information retrieved from http://www.legacy.com/news/advice-and-support/ article/guide-to-writing-an-obituary. Accessed 6 Mar. 2018. 
By contrast, major Brazilian newspapers rarely dedicate a specific section to celebrities' deaths, but usually include news about their passing under diverse sections, e.g., sports, daily life, entertainment, depending on the reason for the deceased's fame. Most newspapers publish paid death notices under (sub)sections called anúncios fúnebres (funeral announcements), mortes (deaths), lista de falecimentos (death list), among others. These texts are generally restricted to providing information about dates of birth and death, and the (bygone) funeral, besides the deceased's name.

According to what has been exposed, we observe that the theme is addressed differently within both cultures/languages, considering the availability of publications devoted to it, and the way they approach death. Furthermore, distinct publications, in both languages/cultures, may use different terminology to refer to texts dedicated to the deceased, whether famous or not. In this article, we use the term 'obituaries' as a generalization for texts written about the dead. However, we differentiate family authored texts from edited texts in what concerns the corpus compilation, as we will explain in the Methodology section.

Due to their comprehensiveness, we believe that obituaries may help with the task of informing about the implications involved in cross-cultural translation training. Loock and Lefebvre-Scodeller (2014) applied quantitative methods of analysis to a corpus of French and North-American obituaries in order to uncover interlanguage differences related to how referring expressions to the deceased are used in both cultures, and they suggest that these differences should be considered for the task of translating such texts. In face of the peculiarities that permeate the theme, we also considered 'obituaries' as an appropriate genre to be practiced with undergraduate Portuguese-English translation students.

\subsection{A translation task}

As part of their semester activities, a class of second-year undergraduate students were requested to read the bilingual graphic 
novel Daytripper (Moon \& Ba 2011, 2014), originally written in English by Brazilian authors and translated into Portuguese by a professional translator. In the story, Brás, the main character, is an obituary writer who dies unexpectedly in different ways, at different ages, at the end of each chapter. As a first activity, we asked students to analyze the translation strategies involved in rendering the obituaries into Portuguese by referring, whenever possible, to Chesterman's (1997) syntactic strategies (loan, calque, literal translation, transposition, etc). As an illustration, below we show three of those obituaries in English (source text), aligned with their published Brazilian Portuguese translations (target text):

\begin{tabular}{|c|c|}
\hline Source text & Target text \\
\hline $\begin{array}{l}\text { When the cancer that had spread } \\
\text { throughout most of his brain finally } \\
\text { took the best of him, Schlomo } \\
\text { Lerner had, at the age of } 89 \text {, been } \\
\text { in love } 274 \text { times. For each of his } \\
\text { lovers the famous painter had made } \\
\text { a portrait. }\end{array}$ & $\begin{array}{l}\text { Quando o câncer que se espalhara } \\
\text { pelo cérebro finalmente o venceu, } \\
\text { Schlomo Lerner tinha, aos } 89 \text { anos, } \\
\text { se apaixonado } 274 \text { vezes. Para } \\
\text { cada amante, o famoso artista } \\
\text { pintara um retrato. }\end{array}$ \\
\hline $\begin{array}{l}\text { He was } 66 \text {, and retired from the } \\
\text { field for } 30 \text { years. It is reported } \\
\text { that his final words to his wife, } \\
\text { Adelaide, on the previous night } \\
\text { were: "I think I'm going to sleep in } \\
\text { late, dear." }\end{array}$ & $\begin{array}{l}\text { Ele tinha } 66 \text { anos, e despedira- } \\
\text { se dos campos há trinta. Diz-se } \\
\text { que suas últimas palavras para a } \\
\text { esposa, Adelaide, na noite anterior, } \\
\text { foram: "Acho que vou dormir até } \\
\text { tarde, querida." }\end{array}$ \\
\hline $\begin{array}{l}\text { For } 40 \text { years, Rodrigo Machado } \\
\text { was the face of the Republic } \\
\text { on foreign soil, working at the } \\
\text { Brazilian Embassy in Cuba, France, } \\
\text { Mozambique, China, Japan and, } \\
\text { most recently, The Congo. }\end{array}$ & $\begin{array}{l}\text { Ao longo de quarenta anos, } \\
\text { Rodrigo Machado representou a } \\
\text { República em solo estrangeiro, } \\
\text { tendo trabalhado nas embaixadas } \\
\text { brasileiras de Cuba, França, } \\
\text { Moçambique, China, Japão e, mais } \\
\text { recentemente, do Congo. }\end{array}$ \\
\hline
\end{tabular}

From the texts in both versions of the book, students correctly concluded that the strategy which was mostly used by the translator was 
literal translation, which is described as being "[...] maximally close to the SL form, but nevertheless grammatical" (Chesterman 1997, 94). Students were then asked to translate authentic North-American death notices into Portuguese. For this second activity, they were advised to choose two texts from major North-American newspapers, or search Obituaries. com $^{2}$ and Legacy.com ${ }^{3}$. While correcting their translations, we could identify recurring problems, which were grouped as: (a) lack of terminology standardization: for example, 'visitation' was rendered as cerimônia, velório and visitação, while missa, cortejo and serviço were suggested equivalents for 'service'; (b) literal translation, resulting in unconventional phraseologies in the target language: 'is survived by' as é sobrevivido(a) por; 'is/was preceded (in death) by' and 'was predeceased by' as élfoi precedido (em/na morte) por'; and (c) incorrect translation, leading to false information: 'wife of $\mathrm{x}$ years' as esposa de $x$ anos, which corresponds, in Portuguese, to the widow's age, not to how long the marriage lasted, as in the source text.

Given the students' difficulty to produce texts that sounded more natural in Portuguese, we resorted to using corpus for equivalence retrieval and awareness of cultural differences. As Franco Aixelá's $(1996,53)$ reminds us, "[e]ach linguistic or national-linguistic community has at its disposal a series of habits, value judgments, classification systems, etc. which sometimes are clearly different and sometimes overlap. This way, cultures create a variability factor the translator will have to take into account." For Schäffner (2000), who writes on translation competence, a sound knowledge of the linguistic system of L1 and L2 is not enough to produce adequate translations. From a list of competences presented by the author, cultural competence, which refers to "general knowledge about historical, political, economic, cultural, etc. aspects in the respective countries." (Schäffner 2000,146) would be an important

\footnotetext{
${ }^{2}$ This website concentrates obituaries of over 1,000 and 40 newspapers from the United States and Canada, respectively.

${ }^{3}$ This website concentrates online obituaries published by more than 1,500 newspapers and 3,500 funeral homes across the United States, Canada, Australia, New Zealand, the United Kingdom, and Europe, and is visited over 40 million times monthly.
} 
competence for translators to possess in order to deal with cultural aspects underlying more obvious linguistic differences. In this regard, we found that the corpus helped to unveil these differences.

\section{A corpus-based translation study}

Both manual comparison of original and translated texts and the analysis of texts belonging to a certain genre in the target language have long been part of the routine of professional translators, but today many of them resort to computer and computational tools, which enable the search for recurring patterns in place of isolated, individual choices.

Defined by McEnery and Hardie $(2012,1)$ as an "[...] area which focuses upon a set of procedures, or methods, for studying language [...]", corpus linguistics involves compiling and processing of sets of texts - corpora - selected in accordance with well-defined criteria, established according to the researcher's aim, and initially examined by computational tools. Introduced by Baker (1993), corpus-based translation studies have been embraced as a way of informing and elucidating the translation process, for terminology retrieval, in the search for conventionality, among others. Fantinuoli and Zanettin (2015), Zanettin (2012), Oakes and Ji (2012) and Kübler and Aston (2010), to name but a few, use original texts and their translations (parallel corpora) and texts of the same domain in different languages (comparable corpora) for translation purposes. We chose corpus linguistics as our methodology to identify patterns, terms and phraseologies in obituaries, and evaluate to what extent they could help translation students with their task.

According to Philip (2009), comparable corpora can reveal the terminology and phraseologies used naturally in the source language, and also help in the identification of discrepancies between textual types produced in different languages and cultures. Therefore, the compilation of a comparable corpus seemed appropriate to reach our objectives. 


\subsection{The study corpus}

Building a comparable Portuguese-English corpus of obituaries resulted in a challenging task, since this kind of publication is much more common in the English-speaking society. According to Gomez (2017), obituaries have circulated in US newspapers since the early $18^{\text {th }}$ century, and this trend only seems to increase in English speaking countries. The Economist, for example, started publishing obituaries in 1995 after nearly 150 years of its existence. The then editor was surprised by an article on the art of obituary and decided to include this section in the paper (Wroe 2017). We could not find trustworthy information about when obituaries started circulating in Brazilian newspapers.

Given the difficulty of finding texts in Brazilian newspapers, we concluded the compilation of the Portuguese subcopus when we reached 100 family authored notices and 100 edited texts from online newspapers published from 2015 to 2017. By contrast, given the huge availability of North-American obituaries, the task of selecting texts for the English subcorpus was much easier, and we could restrict the number of texts per publication to ten in order to prevent idiosyncratic uses by individual publication/editor from being seen as characteristic of the genre. Table 1 summarizes the data of the corpus built for this research:

\begin{tabular}{l|l|l|l|l}
\cline { 2 - 5 } & \multicolumn{2}{c|}{$\begin{array}{l}\text { Brazilian Portuguese } \\
\text { Subcorpus }\end{array}$} & \multicolumn{2}{l}{$\begin{array}{l}\text { North-American English } \\
\text { subcorpus }\end{array}$} \\
\cline { 2 - 5 } & $\begin{array}{l}\text { Nr. of } \\
\text { texts }\end{array}$ & Nr. of tokens & $\begin{array}{l}\text { Nr. of } \\
\text { texts }\end{array}$ & Nr. of tokens \\
\hline $\begin{array}{l}\text { Death } \\
\text { notices }\end{array}$ & 100 & 18,659 & 100 & 25,204 \\
\hline Obituaries & 100 & 35,827 & 100 & 70,055 \\
\hline Total & 200 & 54,486 & 200 & 95,259 \\
\hline
\end{tabular}

Table 1: The study corpus. 
According to what has been stated so far in relation to how death is approached in both cultures, the difference in the number of words (tokens) in the subcorpora comes as no surprise. After all, in what regards death notices, North-American guides advise writers to seek for details of the deceased's life, as we can attest from one of the tips by obituary writing expert Susan Soper:

If you are in a position of writing an obit, try to dig for the intimate details that will keep the person alive in memory: quirks, hobbies, favorite passions, oft-heard quotes, travels, food or unusual pursuits. It doesn't matter if the person was a company president, an electrician, a cook or ballerina, everyone has a story to tell. But that story doesn't come together by itself. Ask friends, children, parents, co-workers and spouses for details they recall and favor. How did the person look or dress? What was his daily routine? Where did she find most happiness? Be creative, look outside the box to find the personality traits and characteristics to recall. ${ }^{4}$

Such type of directive text was not found in Brazilian Portuguese. Moreover, information about funeral arrangements are usually useless in Brazil because burial occurs within 24 hours of death, not allowing enough time for the publication of this kind of text. Not surprisingly, the difference between North-American and Brazilian edited texts is enormous, as North-American obituaries are almost twice as large as their Brazilian Portuguese counterpart. Regardless of the culture/country where they are published, edited obituaries are not supposed to give readers an account of the celebrity's funeral arrangements. Instead, they usually concentrate on why the deceased was famous and the cause of death, besides providing a source for information about the cause of death (Cf. Moses, Marelli 2004). Therefore, the difference in terms of text length may lie elsewhere.

${ }^{4}$ Extracted from: http://www.legacy.com/news/advice-and-support/article/guideto-writing-an-obituary. Access: March 7 $7^{\text {th }}, 2018$. 
Drawing on the anthropologist Edward Hall's concept of 'contexting', Katan $(1999,177)$ claims that “[...] individuals, groups, and cultures (and at different times) have differing priorities with regard to how much information (text) needs to be made explicit for communication to take place." The author designates 'high context cultures' those which rely more on prior knowledge, thus requiring less text to convey information. Low context cultures, on the other hand, are expected to demand more explicitness, since common knowledge is usually insufficient to guarantee communication. In a classificatory cline presented by the author, Latin American cultures appear as being more high-context than North-American's, which may also explain the briefness of Brazilian obituaries.

Regardless of the difference in size of both subcorpora, our study corpus is small if compared to multimillion-word corpora, such as $\mathrm{COCA}^{5}$ and Corpus do Português ${ }^{6}$, for example. What matters here is that the seemingly small size of the study corpus did not prevent us from coming to interesting results in terms of terminology, phraseology and cultural differences, since the corpus is representative of a specialized area. Koester (2010) stresses that more important than the corpus size is its representativeness. Although not very extensive, specialized corpora may lead to quite significant results, as long as they have been built under strict criteria, always considering the purpose of the investigation. Koester (2010) also points out that small corpora have the advantage of allowing a closer relationship between the corpus and the contexts in which their texts were produced. Additionally, as in research with small corpora the compiler is also the analyst, the degree of familiarity with the context tends to be higher, allowing quantitative data revealed by the corpus to be complemented by manual analysis. Moreover, both paid and edited notices are prototypical texts

${ }^{5}$ Corpus of Contemporary American English. Available at: https://corpus.byu. edu/COCA/.

${ }^{6}$ Available at: http://www.corpusdoportugues.org/. 
which, despite sharing specific personal information, follow rather fixed structures (Moses, Marelli 2004).

\section{Discussion}

In this section we discuss the findings enabled by the quantitative and qualitative analysis of the study corpus. After analyzing edited and family authored texts as a whole and separately by using computational tool, we manually observed the keywords.

\subsection{Quantitative analysis}

We retrieved simple and compound (combinations of two to five words) wordlists from both subcorpora using WordSmith Tools 6.0 (Scott 2012). We then compared those words to those of general language reference corpora in order to retrieve keywords, i.e. words with occur significantly more often in the study corpus. For this study, we used a sample of the OANC (Open American National Corpus) ${ }^{7}$ as reference for the North-American subcorpus, and a sample of the LacioRef ${ }^{8}$ for the Brazilian Portuguese subcorpus. We considered a frequency cut-off of 10 for the keywords, that is, to be considered a keyword, a word or combination should recur at least ten times, and the $p$-value was established at 0,0001 , which means that there is a one-in-ten-thousand $(0,01 \%)$ chance of a word to be wrongly considered key. Considering those settings, the tool retrieved 427 single and 449 compound keywords from the NorthAmerican subcorpus, and 253 single and 169 compound keywords from the Brazilian Portuguese subcorpus.

\footnotetext{
${ }^{7}$ Available at: http://www.anc.org/data/oanc/download/. Accessed April 4, 2018.

${ }^{8}$ Extracted from: http://www.nilc.icmc.usp.br/nilc/projects/lacio-web.htm. Accessed 1 Jan. 2014.
} 


\subsection{Qualitative analysis}

The lexical and grammatical characteristics of the two lists of keywords allowed us to draw a number of conclusions about terminological and cultural differences which permeate Brazilian Portuguese and American English obituaries. Function words prepositions, pronouns, articles, auxiliary verbs, etc. - , which are usually neutralized in keyword lists given their repetitiveness in basically every text, have a high keyness in the English subcorpus. Since Portuguese verbs display a high degree of inflection, the repetition of subject personal pronouns may be unnecessary, differently from English, what explains the high keyness of 'he' and 'she', but not of their counterparts - ele and ela - in Portuguese. Possessive adjectives are also underused in Portuguese, if compared to English. For example, a usual combination of words in English is ' $x$ is survived by his wife', whereas, in Portuguese, we find recurrence of $x$ deixa a esposa [x leaves the wife].

By retrieving concordance lines with the lexical keywords - excluding proper names, since our interest lies in terms and phraseologies which are characteristic of the genre -, we manually selected recurring terms and phraseologies and semantically grouped them by adapting the structures proposed by Moses and Marelli (2004): 'birth and life'; 'school, work and hobby'; 'praise and achievements'; 'kin'; 'cause and circumstance of death'; 'funeral arrangements'; and 'requests and wishes'.

In what concerns the keywords of 'obituaries' and 'death notices' as a whole, we observe that most categories inspired by Moses and Marelli's (2004) recur in both languages. Nevertheless, their content reveals significant differences, except for the three first 'birth and life', 'school/work/hobby' and 'praise and achievements' -, which, despite showing more variation in English, the content does not substantially differ, and the higher number of keywords in English is easily explained by the difference in the number of words in both subcorpora. 
Category 'kin' shows that, in the Brazilian Portuguese subcorpus, only the deceased's nuclear family - offspring, grandchildren and spouse (filhos, netos, viúva(o)) - is mentioned, besides the generic term familiares [relatives]. In English, on the other hand, the relationships mentioned reaches up extended family, including even cousins, nephews, etc. Another noteworthy characteristic in this group is the reference to these family members. Mentioning family members who had already died, through phraseologies such as 'was predeceased by' and 'is/was preceded in death by' is also exclusive of the American English subcorpus.

Combinations of words in Brazilian Portuguese are formed by the verb 'deixar' [lit. leave], either in the present or past - deixa and deixou, respectively -, followed by name and kinship, limited to spouse and offspring, showing that the action is described from the deceased's point of view, i.e. the one who 'left the scene'. Conversely, equivalent references in English are demonstrated from the perspective of the ones who experience the action, i.e. the living ones - hence the use of the passive construction 'is survived by' -, and references are made to whoever is included, and the list may be very long, especially in death notices.

The circumstances of death also indicate differences in both languages. In English we observed a recurring tendency of euphemizing the passing by using the adverb 'peacefully' and the phraseology 'surrounded by his/her (loving) family', whereas in Portuguese it is common to mention where the death occurred at home/at the hospital (em casa/no hospital) -, but not how. Words and phrases related to funeral arrangements also show many differences in how both cultures deal with the theme. As previously mentioned, funerals in Brazil last no longer than 24 hours; therefore, when obituaries and death notices are published, they are usually finished. This explains why Brazilian rituals are mostly described in the past - foi velado/sepultado, o velório/ sepultamento foi realizado, etc. In contrast, North-American rituals are reported in the future - 'mass/visitation/funeral will be followed by', 'burial/inurnment/committal will follow', 'Memorial 
Service will be held', 'interment will be private', etc. In addition to this difference in verb tense, the 'funeral arrangements' category shows that while Brazilian death rituals are usually restricted to velório (lit. 'wake') - which hardly lasts for more than one day - and sepultamento/enterro (burial/interment/entombment), being the reference to cerimonia (ceremony) basically restricted to Jewish and cremation rituals. North American rituals, on the other hand, may comprehend other steps, such as 'celebration of life', 'Mass', 'visitation', 'graveside service', 'memorial service' and 'viewing'.

Funeral homes and agências funerárias (lit. funeral agencies) are in charge of preparing the deceased for the rituals in the United States and in Brazil, respectively. Nevertheless, we cannot claim that they are equivalent, though. Not only are North-American funeral homes responsible for embalming the body in order to delay decomposition, but they also provide an area where memorial services take place. In contrast, funerárias in Brazil are usually responsible solely for placing the body in the coffin and transport it to the cemetery so that family and friends can pay their respect. Moreover, reference to corpo (body/corpse) recurs only in the Brazilian Portuguese subcorpus, used in phraseologies such as $O$ corpo foi sepultado [the body was buried] and o corpo está sendo velado [the body is being waken], whereas English phraseologies do not make reference to the body, but may include the deceased's name - 'A celebration of (x's life) will be held at/on [...]', 'A Memorial Service will be held...', etc.

Requests for donations are restricted to the North-American obituaries, being introduced by the phraseology 'In lieu of flowers' and finishing with the name of one or more institutions that may have cared for the deceased. Brazilian obituaries are more religiousoriented, wishing the deceased a peaceful passing to the afterlife and condoling with the surviving family.

In what regards North-American texts, we concluded, in accordance with Moses and Marelli (2004), that family authored texts greatly differ from edited texts both in terms of structure and lexical variation, and as such, they could be analysed separately. 
Nevertheless, a similar comparison would result unfruitful between Brazilian Portuguese texts, since, as aforementioned, death notices are rare and very short.

\section{Conclusion}

Writing from a postcolonial perspective, Simon (1997, 464) declares:

[t]he solutions to many of the translator's dilemmas are not to be found in dictionaries, but rather in an understanding of the way language is tied to local realities, to literary forms, and to changing identities. Translators must constantly make decisions about the cultural meaning which language carries, and evaluate the degree to which the two different worlds they inhabit are the same.

Our investigation of simple and compound keywords between obituaries written in English and in Portuguese revealed differences that go beyond grammar and lexicon. We observed that the way North-Americans and Brazilians pay their respect to the dead is embedded in the language used in these texts. These differences are, therefore, of a cultural nature and impact on the way one translates. With the corpus, not only did our students improve on their choices of terminology and phraseology for their translations, but they also realized that the previously prevailing choice of literal translation was not enough to account for these differences, that they needed to use cultural competence to render elements for which there are no direct equivalent in Portuguese. In our class discussions we made students aware that they needed to approach the corpus with inquisitive minds so that they could duly interpret what it has to share. As Jakobson ([1959] 2000, 141) points out, "[1] anguages differ essentially in what they must convey and not 
in what they may convey". Therefore, the lack of equivalence that the corpus revealed tells us that there are some aspects related to funeral ritual about which Brazilians are not required to think because they are not part of their practices. However, when translating the North-American rituals into Portuguese, translators need to consider that these aspects do exist in the other culture so that they can try to find ways (translation strategies) to account for them in the target text. In this regard, the corpus helped these students reflect on the fact that in order to render obtuaries and death notices in a more adequate fashion, they also need to think beyond the dictionary.

\section{References}

Baker, Mona. "Corpus linguistics and translation studies: Implications and applications". Text and Technology: In Honour of John Sinclair edited by Mona Baker; Gill Francis; Elena Tognini-Bonelli, John Benjamins, (1993): 233-250.

Bates, Ashley; Ian Monroe; Ming Zhuang (eds.). The state of the American obituary. Northwestern University, 2009. https://www.ianmonroe.com/wpcontent/uploads/2009/10/StateOfTheAmericanObituary_Nov2009.pdf. Accessed 5 May 2017.

Chesterman, Andrew. Memes of Translation: The Spread of Ideas in Translation Theory. Amsterdam-Philadelphia, John Benjamins, 1997.

Cimminiello, Maria C. S. V.; Tambelli, Alba L. R. "Obituário: um gênero em construção?”. Revista Interfaces, 3 (2012): 27-32.

Closer. Dir. Mike Nichols, performances by Julia Roberts, Jude Law, Natalie Portman, and Clive Owen. Columbia Pictures, 2004. DVD. 
Eid, Mushira. The world of obituaries: gender across cultures and over time. Detroit, Wayne State University Press, 2002.

Fantinuoli, C.; Zanettin, F. (eds.) New directions in corpus-based translation studies. Berlin, Language Science Press, 2015.

Fioravanti, Carlos. Diante do silêncio sobre a morte. Revista Pesquisa FAPESP, São Paulo, edição 242, (2016): 84-87.

Franco Aixelá, Javier. "Culture-specific items in translation". Translation power subversion, edited by R Álvarez.; M.C.-Á Vidal ,Clevedon, 8 (1996): 52-78.

Gomez, Hannelore. "A Closer Look into the Life of Ordinary Translators through Unordinary Sources: The Use of Obituaries as a Microhistory Tool to Study Translators and Translation in Ohio". New Voices in Translation Studies, 16 (2017): 55-83.

Jakobson, Roman. (1959). "On linguistic aspects of translation". The Translation Studies Reader, edited by Lawrence Venuti, Routledge, (2000): 138-143.

Katan, D. Translating cultures: an introduction for translators, interpreters and mediators. St. Jerome, Manchester, 1999.

Koester, Almut. "Building small specialised corpora". The Routledge handbook of Corpus Linguistics, edited by Anne O'Keeffe; Michael McCarthy, Routledge, (2010): 66-79.

Kübler, Natalie; Aston, Guy. "Using corpora in translation". The Routledge handbook of Corpus Linguistics, edited by Anne O'Keeffe; Michael McCarthy, Routledge, (2010): 501-515.

Laviosa, Sara. Corpus-based translation studies: theory, findings, applications. Amsterdam, Rodopi, 2002.

Loock, Rudy; Lefebvre-Scodeller, Cindy. "Writing about the dead: a corpusbased study on how to refer to the deceased in English vs French obituaries 
and its consequences for translation". Current trends in translation teaching and learning, edited by Mikel Garant, University of Helsinki, (2014): 15-150.

McEnery, Tony; Hardie, Andrew. Corpus Linguistics: method, theory and practice. Edinburgh: Cambridge University Press, 2012.

Moon, Fábio; BA, Gabriel. Daytripper. São Paulo, Panini, 2014.

. Daytripper. Burbank, Vertigo, 2011.

Moore, Stephen H. "Disinterring ideology from a corpus of obituaries: a critical post mortem”. Discourse \& Society, 13.4 (2002): 495-536.

Moses, R. A. \& Marelli, G. D., edited by Wai Fong Chiang, Elaine Chun, Laura Mahalingappa and Siri Mehus "Obituaries and the Discursive Construction of Dying and Living”. Texas Linguistic Forum 47, Proceedings of the Eleventh Annual Symposium about Language and Society, Austin, Texas, 2004.

Oakes, Michael; JI, Meng. (eds.) Quantitative methods in corpus-based translation studies. Amsterdam, John Benjamins, 2012.

Philip, Gill. "Arriving at equivalence: making a case for comparable general reference corpora in translation studies". Corpus use and translating, edited by Allison Beeby; Patricia R. Inés; Pilar Sánchez-Gijón,John Benjamins, (2009): 59-73.

Schäffner, Chirstina. "Running before Walking? Designing a Translation Programme at Undergraduate Level". Developing Translation Competence, edited by Christina Schäffner and Beverly Adab. Benjamins, (2000): 143-156.

Simon, Sherry. "Translation, postcolonialism and cultural studies". Meta, XLII. 2 (1997): 462-477.

Starck, Nigel. "Sex after death: the obituary as an erratic record of proclivity". Mortality, 14.4 (2009): 338-354. 
924.

. "Death can make a difference". Journalism Studies, 9.6 (2008): 911-

. Life after death: the art of the obituary. Melbourne, Melbourne University Press, 2006.

. "Posthumous Parallel and Parallax: the obituary revival on three continents". Journalism Studies, 6.3 (2005): 267-283.

Scott, M. WordSmith Tools 6.0. Oxford, Oxford University Press, 2012.

Vieira, W. O obituário contemporâneo no jornal e nas coletâneas: uma discussão sobre gênero textual, biografia e sociedade. Dissertação de Mestrado, Escola de Artes, Ciências e Humanidades, Universidade de São Paulo, São Paulo, 2014.

Wroe, Ann. "The art of writing an obituary: capturing the essence of a life in 1,000 words or fewer." The Economist, https://medium.economist.com/the-artof-writing-an-obituary-e64a546222f. Accessed 27 Aug. 2017.

Zanettin, Federico. Translation-driven corpus: corpus resources for descriptive and applied translation studies. Manchester, St. Jerome, 2012.

Recebido em: 11/04/2018

Aceito em: 27/07/2018

Publicado em setembro de 2018

Rozane Rodrigues Rebechi. E-mail: rozanereb@gmail.com ORCID: http://orcid.org/0000-0002-1878-7548

Márcia Moura da Silva. E-mail: marciamouraprof@gmail.com

ORCID: https://orcid.org/0000-0002-4788-1461 